
Multidisciplinary
SCIENTIFIC JOURNAL
OF MARITIME RESEARCH

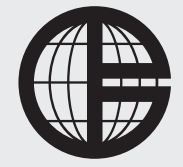
University of Rijeka
CLTY OF MARITIME STUDIES
Multidisciplinarni
znanstveni časopis
POMORSTVO

\title{
Risk assessment and exemption approval procedure for the semi-closed seas according to the International Convention for the Control and Management of Ships' Ballast Water and Sediments, 2004
}

\author{
Katarina Balić ${ }^{1}$, Damir Zec ${ }^{2}$ \\ ${ }^{1}$ University of Split, Ulica Ruđera Boškovića 31, 21000 Split, Croatia, e-mail: katarina.balic@unist.hr \\ ${ }^{2}$ University of Rijeka, Faculty of Maritime Studies, Studentska ul. 2, 51000 Rijeka, Croatia e-mail: zec@pfri.uniri.hr
}

\section{ABSTRACT}

The paper analyses statutory foundations applicable to ships requiring to be exempted from the mandatory installation of the ballast water management system. In particular, it deals with ships sailing on regular international lines but within the semi-closed seas, such as the Adriatic Sea. The legal framework is set out in the International Convention for the Control and Management of Ships' Ballast Water and Sediments (BWM, 2004), the IMO Guidelines for Risk Assessment A-4 (G7), and the Croatian Ordinance on Ballast Water Control and Management, 2012 [Pravilnik o upravljanju i nadzoru balastnih voda]. The paper presents the model procedure to be followed by main stakeholders, mainly national maritime administrations and shipping companies.

The paper outlines the main advantages and disadvantages of the whole process and analyses several cases of good practice. Furthermore, the main stakeholders in the approval procedure and their responsibilities are described, available risk assessment models are analysed, with the particular emphasis on the species-specific risk assessment method as the most preferred method. Finally, the need for cooperation between the involved states and their maritime administrations is considered. It is concluded that bilateral and regional cooperations are an essential element in preserving the marine environment of any sea area. In that respect, the proposed model of the BWM system exemption approval in closed and semi-closed seas, such as the Adriatic Sea, is essential for shipping companies connecting ports in different countries on regular routes. Although demanding in respect of efforts and time, a procedure is viable and may be carried out in due time and with satisfactory outcomes.
\end{abstract}

\section{ARTICLE IN FO}

Review article

Received 27 August 2020

Accepted 23 September 2021

\section{Key words:}

BWM Convention

Ballast water

Exemption approval procedure

Semi-closed sea

Adriatic Sea

\section{Introduction}

In recent years, mainly due to the globalisation and human activities related to the sea, such as maritime transport, fish farming and fishery, a significant introduction of non-indigenous species (NIS) into the marine environment is recorded $[4,29]$. According to the available information, over 800 non-indigenous species (NIS) have been identified in the European seas [29], presenting a significant risk for the local environment where introduced. Particularly dangerous are the invasive species. Invasive species may pose significant risks on the marine ecosystem, its functionality and biodiversity, thereby causing negative ecological, economic and human health consequences [21, 25, 29, 31]. According to the EU Biodiversity
Strategy [8], the introduction of invasive non-indigenous species presents a growing threat to the biological diversity in Europe.

There are different ways of introducing non-indigenous species, among which the primary way of introduction is marine transport [10]. With the ever-increasing sizes and numbers of ships employed in the marine traffic, the importance of this issue is growing as well. Nonindigenous species may be introduced in the ship's ballast water, as underwater surface fouling and on anchors [16]. Based on the actual trends, it may be concluded that the problem still has not reached its peak [15]. Invasive nonindigenous species are considered to be the second most important cause of biodiversity loss, and Institute for European Environmental Policy - IEEP has estimated that 
they cost the EU at least 12 billion and probably over 20 billion Euro per year. They present difficult challenges for EU Member States because of the need for close cooperation across borders and between different policy areas, economic sectors and stakeholders. IEEP has partnered with the European and global experts to become the initiator in shaping the European Commission's invasive nonindigenous species policy [30]. At the European Union level, several documents are dealing with the problem, the most important being the EU Biodiversity Strategy [8], and the Marine Strategy Framework Directive [9].

The International Conference on Managing the Ship's Ballast Water and Sediments held in 2004 at the International Maritime Organization (IMO) headquarters in London adopted the International Convention for the Control and Management of Ships' Ballast Water and Sediments (the BWM Convention) [14]. The purpose of the BWM Convention is to prevent spreading of harmful sea organisms from one region to another by establishing standards and procedures of managing and controlling the ship's ballast water and sediments [15]. Besides, the IMO member states have developed 14 guidelines facilitating the application of the BWM Convention, some of them already being revised [15].

On 8 September 2017, the Ballast Water Management Convention came into force. Of the six states with access to the Adriatic Sea, three states have already ratified the BWM Convention: Albania in 2008, Croatia in 2010 and Montenegro in 2011; Montenegro [18] and Croatia also adopted their national legislations harmonised with the BWM Convention; and Croatia also adopted further national by-laws [17]. Italy, although it has not ratified the BWM Convention, enacted the Minister's Regulation on Establishing Administrative Procedures Related to Approving the Ballast Water Management System [23].

The Risk Assessment Guidelines A-4 (G7) provide guidance on risk assessment principles and methods, required information, advice on the implementation of the risk assessment methods, exemption approval procedures, consultation and communication processes, information for exemption review and advice related to technical assistance, domestic and regional cooperation [13]. Exemptions from BWM requirements may be given when a RA, prepared according to the G7 Guidelines, results in an acceptable low risk. The discharge of ballast water will be assessed as posing a low risk in conditions when:

- the ballast water is moved between ports with freshwater $(<0.5 \mathrm{psu})$ and fully marine conditions $(>30$ $\mathrm{psu}$ ), independent of whether the donor and recipient ports are in the same region; or

- the ballast water is from a donor port that does not contain HAOP and is from the same region as the recipient port [16].

As stipulated in the Rule A-4 of the BWM Convention, ships that are assessed as presenting a low risk to the environment might be exempted from the installation of the ballast water management system (BWMS). Therefore, exemptions from afore-mentioned rules may apply to ship or ships on a voyage or voyages between specified ports or locations or to a ship which operates exclusively between specified ports or locations.

The Adriatic Sea is exposed to the potential introduction of non-indigenous species by intensive maritime traffic, particularly in its northern part mainly due to several comparatively large cargo ports such as Trieste, Venice and Ravenna in Italy, Koper in Slovenia and Rijeka in Croatia. Furthermore, since the Adriatic Sea is considered as a common resource of several countries, the efficient application of the BWM Convention regulations requires the cooperation of all Adriatic states on the particularities that have not been solved by the national or international legal framework. Among the first steps in regulating exemptions provided for in the BWM Convention is an agreement among maritime administrations on the risk assessment procedure and, based on this, implementation of exemptions for the semi-closed seas [24]. Consequently, this paper proposes a procedure for issuing BWMS exemption to be followed by all stakeholders namely ships sailing on regular lines, within the semi-closed seas, such as the Adriatic Sea.

\section{Exemption approval procedure}

By ratifying the BWM Convention Croatia has committed to apply the ballast water management system in the following cases:

- ships entitled to fly the flag of a Party and

- ships not entitled to fly the flag of a Party but which operate under the authority of a Party.

However, installing the ballast water treatment system on the ships operating at regular lines in the Adriatic Sea, because of their age, is probably economically unviable (for example, the ships serving the international shipping line Split - Ancona). According to Croatia's Ordinance on Ballast Water Management and Control, the responsible Ministry of the Sea, Transport and Infrastructure may exempt a ship or ships ballasting and deballasting in Croatia, and trading between particular ports or areas, from applying the ballast water management system. The exemption may be approved only following the risk assessment performed according to the Risk Assessment Guidelines (G7) and provided that the ship does not mix ballast water and sediments with ballast water and sediments taken in another area or port [17].

\subsection{Risk assessment}

Applying for an exemption requires preparing a risk assessment. Such risk assessment, as a formal and structured procedure identifying potential unwanted events (hazards) [6], is aimed to determine the risk level posed by the unloaded ballast water. The risk frequencies and 
consequences (risk incidents) are defined within the hazards identified in the assessment procedure and depend on the risk assessment method applied [6].

Three risk assessment methods are identified in the Guidelines [13]:

- environmental matching risk assessment,

- species biogeographical risk assessment, and

- species-specific risk assessment.

The environmental matching risk assessment relies on comparing environmental conditions at different locations, where the risk is acceptable only if one port is located in the freshwater area $\left(<0.5 \mathrm{psu}^{1}\right)$, and the other one is located in an area with the sea environment (>30 psu) [6]. The species biogeographical risk assessment as a method compares the species found in different areas. By doing so, it aims to assess similarity of the environment as a measure proportional to the species invasiveness risk. Finally, the species-specific risk assessment identifies target species to assess their survival potential in other areas [13].

A model for assessing the risk in the Adriatic Sea, fully harmonised with the principles detailed in the Risk Assessment Guidelines A-4 (G7), is developed within the project Ballast Water System for Adriatic Sea Protection (BALMAS) [23]. The model proposed combines all three risk assessment methods. As a part of the project activities the environmental screening of the numerous Adriatic ports has been carried out: Bari, Ancona, Venice and Triest in Italy, Koper in Slovenia, Rijeka, Pula, Šibenik, Split and Ploče in Croatia, Bar in Montenegro and Durrès in Albania. The project identified and integrated the activities necessary to enable a long-term ecologically and financially efficient and, for the maritime traffic, viable implementation of the BWM Convention measures in the Adriatic Sea area [7].

The project's final report presents information on temperature, salinity and nutrients in the ports mentioned above [20]. At the investigated area, considerable number of NIS were detected, e.g. 23 NIS in macrozoobenthos community ( 2 in the ports of Ploče, Split and Šibenik, 3 in Bar and Bari, 4 in Rijeka, 5 in Koper and Venezia, 6 in Pula and Trieste, and 7 in Ancona) and 14 NIS in macroalgae community ( 1 in the port of Koper, 2 in Ancona, Bari, Ploče and Šibenik, 3 in Venezia, 4 in Durres, and 9 in Split). Among them the most invasive species is Undaria pinnatifida, which reduces biodiversity by overgrowing in native habitats $[19,20]$.

Consequently, due to relatively limited area of the Adriatic Sea, the closeness of the biogeographical areas, similar temperatures and salinity, with relatively similar annual differences $[19,20]$, there is a significant possibility of natural transfer and survival of the organisms. In such cases, the applicable risk assessment method for the exemption procedure is the species-specific risk assessment

1 Practical salinity unit. method. The method, based on the information on the particular species' physiological characteristics, aims to assess their survival probabilities in a new environment [6] while taking into account the environmental damages they may cause in the new environment.

Unfortunately, the information on the numbers and methods of introduction of non-indigenous species and their behaviour in the area under consideration are still quite scarce. Missing data includes the data on the species' invasiveness in the new environment, degree of tolerance to the environmental conditions, availability of food, reproduction and its impact on the invasive species' survival, as well as predictions of potential damages [6]. Furthermore, one of the challenges intrinsic to this risk assessment method is the fact that indigenous species may become invasive when transferred to another region. If in specific ports the same species already exits but at different depths or in a different number, each case is to be separately examined, because its further introduction may trigger a different behaviour [5].

As defined in the Risk Assessment Guidelines A-4 (G7) $[13,15]$, the risk assessment procedure following the species-specific risk assessment method is to take into account at least the following criteria [11]: (a) relation to ballast water as the introduction vector, (b) impact degree, (c) information on the previous introduction(s) of the targeted species, and (d) current distribution of the species in its original biogeographical region, if necessary also in other biogeographical regions. The risk could be deemed high if the targeted species are identified, and its survival in the port is deemed possible. As a rule, a species with higher ecological tolerance and a higher reproduction rate has a more considerable invasiveness potential [11].

\subsection{Applying for exemption approval}

Applying for exemption starts by initial information provided by the shipping company interested to obtain the exemption from the Ministry of the Sea, Transport and Infrastructure. The exemption application is to contain at least general information, information on the ship and information on the ship's route.

The general information should include at least information on the period the exemption is applied for, and the reason for applying as it is stated in the Risk Assessment Guidelines A-4 (G7). The information on the ship should include: the ship's name, the IMO number, a port of registry, gross tonnage, owners name or title, call sign, possibility of managing ballast water including the ballast water treatment technology (if it exists), a copy of the ship's Ballast Water Management Plan, and the history of managing ballast water and sediments. The information on the route should include the departure and the arrival ports. If an exemption is required only for a single voyage, the dates and times of the departure and arrival should be stated as well. If an exemption is requested for multiple 
voyages, data provided should include at least the following: voyage frequency, regularity and assessment of the ballast water to be discharged in the exemption period, dates and times of departures and arrivals, particularities on any voyages of the ship to ports other than those stated as regularly called in during the exemption period, and the total number of voyages and quantities of the ballast water discharged during the exemption period [13].

The BWM Convention provides for two types of approving the exemption. One is the automatic exemption, while the other is applied when the company proposes an exemption according to the Risk Assessment Guidelines A-4 (G7) [28]. The automatic exemptions are granted to:

- ships not designed or constructed to carry Ballast Water,

- any warship, naval auxiliary or other ship owned or operated by a State and used, for the time being, only on government non-commercial service,

- permanent Ballast Water in sealed tanks on ships, that is not subject to discharge $[14,27]$.

The exemption may be issued in cases when all the data and assessments are already carried out for similar ship or ships and known routes. It is up to the national administration to decide whether the ship, the route and environment are sufficiently similar to the existing one and issuance of the exemption will not pose additional risk to the environment.

The exemptions may be approved only for the voyages between specific ports or locations, or for the ships trading only between specific ports or locations, and according to the relevant Rik Assessment Guidelines (G7). The exemption will come into force once communicated to the IMO and agreed with the involved states. It may remain in force up to 5 years, subject to revisions during the time of validity. Furthermore, the ship during that time must not disturb or damage the environment, human health, properties or resources of the adjacent or other states. Any state that may be affected by adverse consequences is to be called to consultations aimed to solve the identified problems [22].

Once the company applied, the responsible Ministry (in the case of the Republic of Croatia it is the Ministry of the Sea, Transport and Infrastructure) must consult other interested states. During consultations with other states, the responsible maritime administration should agree on the appropriateness of the used risk assessment procedure [24]. In principle, after being provided with the application and necessary information, the interested State may:

- approve the exemption request without comments or conditions,

- approve the exemption with comments or conditions.

If the responsible Ministry does not receive a response within the prescribed time, it may consider that application for the exemption is approved without comments or conditions. If an interested state does not approve the ex- emption, it is expected to explain the reasons for such decision. In that case, the interested State may approve the exemption with clearly explained conditions and limitations or may reject the request [13].

\section{Proposed exemption approval procedure in Croatia}

In the Republic of Croatia, the Ministry responsible for the environmental protection from shipboard pollutions is the Ministry of the Sea, Transport and Infrastructure. Consequently, it is the authority in charge of the implementation of the BWM Convention, 2004. According to the Maritime Code of the Republic of Croatia, company is a natural or legal person who has assumed the responsibility for managing a ship from the ship owner, and that has by assuming this responsibility assumed the authorities and liabilities in accordance with the International Safety Management.

Based on the requirements and preconditions mentioned above, the exemption approval procedure should consist of several actions and decisions, each one initiated or carried out by one of the stakeholders. The flowchart of the procedure is attached as Figure I. The procedure consist of the following steps:

(1) The company contacts the Ministry and provides (initial) data on route(s) and ship(s) under consideration for the exemption.

(2) The Ministry notifies the company about the requirements needed to fulfill an application and about the expected credibility of the submitted documentation including the general conditions and requirements for exemption.

(3) The Ministry initiates consultations with the State(s) where intended port(s) of call are located (interested States). States should exchange information on the risk assessment method, quality of the data used in the assessment, reasoning behind the risk assessment, and all other regulations or requirements that may be requested in respect of the exemption under consideration.

(4) The company (or expert legal entity on behalf of the company) prepares the risk assessment. The decision on further actions depends on whether the identified and measured risks are deemed acceptable. The shipping company may apply for an exemption when the risk is assessed as acceptably low [6]; if the risk is assessed as medium or high, than it is reasonable for the company to abandon the further steps.

(5) The company files its application to the Ministry requesting the issuance of the BWM Exemption Certificate.

(6) Ministry receives application and checks whether or not the application fulfills the requirements. If the Ministry considers identified risks as unacceptably high, it shall reject the issuance and terminate the 


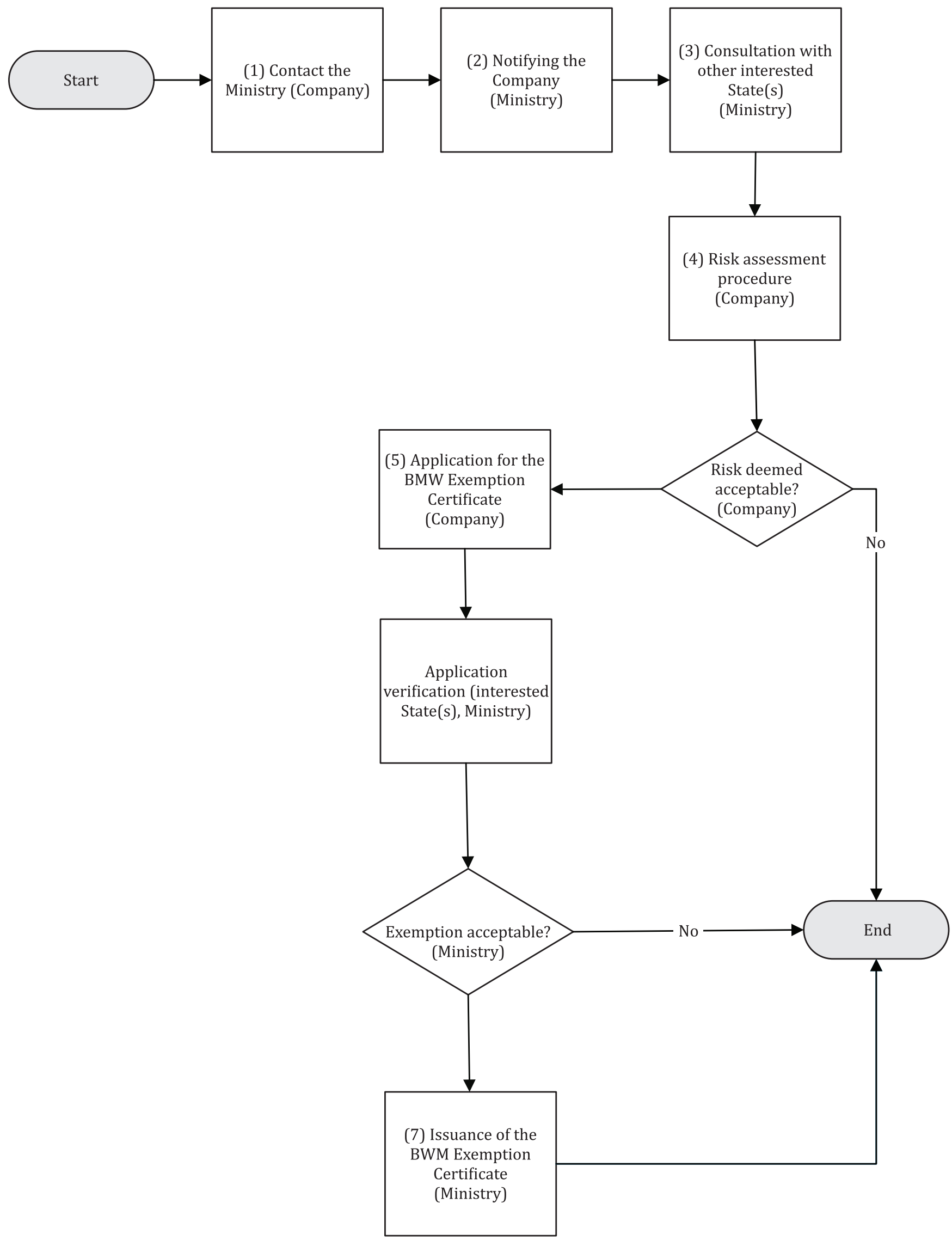

Figure 1 Proposed exemption approval procedure 
procedure. Otherwise, should the risk be regarded as low, the procedure shall continue. The decision on further actions depends on whether the interested State(s) find submitted documents to be sufficient for issuance of the certificate.

(7) After the interested State(s) accepts the proposed exemption, the Ministry (or the recognised organisation on its behalf) issues the BWM Exemption Certificate.

\section{Discussion}

The proposed exemption approval procedure has both advantages and disadvantages.

In respect of the disadvantages, it is to be emphasised that this is an expensive and demanding process involving at least two national administrations. In that respect, it has to be emphasised that all Adriatic littoral states did not ratify the BWM Convention. The main issue here is a request for the State to implement the Convention (i.e. accept exemption) which has not yet been ratified. For example, in the case of a Croatian company initiating the exemption procedure for a ship sailing between Croatia and Italy, it is not clear whether the Italian administration should follow the procedure prescribed by the BWM Convention which it did not ratify.

Furthermore, the exemption risk assessment must be renewed every five years, and in the meantime also reviewed no later than 36 months after being issued, recommended as often as within 12 months (points 7.6 and 10.2 of the Risk Assessment Guidelines A-4 (G7)).

Another disadvantage is that a ship with the exemption cannot serve other shipping lines. Such a situation imposes significant operational restrictions on company management.

Also, an exemption can be temporarily withdrawn if the actual risk related to the particular voyage has become higher than it was at the moment of the initial risk assessment and exemption approval. A notable example of such events is the sudden growth of populations of the harmful sea organisms and pathogens (algae blooms) that may be transferred in the ballast water (point 10.4 of the Risk Assessment Guidelines A-4 (G7)).

The main advantage of the exemption approach is significant financial savings for the shipowner, especially if many ships are sailing on such international lines. In this case, initial savings may reach a few million USD with additional saving every year on maintenance costs.

It is worth noting that the procedure, as it is laid down in the Guidelines, requires significant environmental research, thus enriching the knowledge base on marine habitats and species inhabiting the most endangered parts of the coastline, i.e. those within or close to the port areas.

The advantages of the exemption procedure are best seen in the cases of good practice [1, 2, 3, 22, 27]. There are several cases of good practice of mutually harmonised procedures for issuance of the exemption certificates in respect to the ballast water management system.

Probably the most notable example is a procedure agreed by HELCOM and OSPAR countries which developed the HELCOM/OSPAR Commonly Agreed Procedure of Approving Exemptions from the BWM Convention [3]. This procedure establishes an agreed-upon procedure of approving exemptions for the North-East Atlantic and the Baltic Sea [24].

In the USA exemptions may be approved for:

a) vessels trading within the jurisdiction of one Cost Guard authority,

b) vessels sailing not more than $10 \mathrm{NM}$ and not passing physical barriers (e.g., locks),

c) vessels sailing on the Great Lakes only, and

d) vessels of internal and outer navigation not exceeding 1600 GT [2, 22].

In Canada, there are exemptions applied to the vessels sailing in the Canadian waters only, vessels sailing in the Great Lakes, small research vessels, vessels with permanent ballast, and government's vessels [1].

The above cases of good practice in the countries that have adopted exemption approval procedures offer significant benefits to the companies operating within the prescribed limits. In respect of the Adriatic Sea, the benefits may not be as substantial as, for example, in the case of OSPAR HELCOM countries. However, even in the Adriatic Sea area, financial benefits will justify the efforts required to come to an agreement on the harmonised exemption system for the implementation of the BWM Convention. In that respect, the Ministry of the Sea, Transport and Infrastructure of the Republic of Croatia should be committed to contact other national maritime administrations and initiate deliberations.

\section{Conclusion}

Full and harmonised implementation of the exemption schema as provided under Regulation A- 4 of the IMO Ballast Water Management Convention offers significant benefits for shipowners but also for national authorities. Legal basis for such an approach is already laid down in the Ordinance on Ballast Water Management and Control.

With the purpose to ensure the effective implementation of the scheme, it is necessary to have harmonised procedure in all Adriatic littoral countries. Consequently, the Ministry of the Sea, Transport and Infrastructure should consider initiating deliberations with respective national administration on the harmonised procedure. Considering the number of lines between Croatian and Italian ports, it seems reasonable to start the process by inviting the Italian administration, and later on, to extend the participation on all Adriatic states. The primary purpose of approving the exemption procedure is significant financial savings for shipowners. The model proposed in this paper 
may be used as an initial proposal. The procedure consist of the following steps:

(1) Contact the Ministry (Company)

(2) Notify the Company (Ministry)

(3) Consultation with other interested State(s) (Ministry)

(4) Risk assessment procedure (Company)

(5) Application for the BWM Exemption Certificate (Company)

(6) Application verification (interested State(s), Ministry)

(7) Issuance for the BWM Exemption Certificate (Ministry)

Finally, the species-specific risk assessment, as the primary tool used to assess risks in areas where no significant differences in salinity and temperature exist, may be used as a basis for further cooperation among research institutions and support maritime traffic as well as environmental protection of the Adriatic Sea.

Funding: The research presented in the manuscript did not receive any external funding.

Author Contributions: Data Collection, Data curation, Research, Conceptualization, Methodology, Writing, Review, Editing, all authors contributed equally.

\section{References}

[1] Albert, R.J., Lishman, J.M., Saxena, J.R. (2013) Ballast water regulations and the move toward concentration-based numeric discharge limits. Ecol. Appl. 23 (2), 289-300.

[2] Ballast Water Treatment Advisory ABS, (2014) pp. 80, available at http://ww2.eagle.org/content/dam/eagle/ publications/2014/BWTAdvisory14312rev3.pdf. (accessed 31 May 2020)

[3] Baltic Marine Environment Protection Commission (2013) HELCOM/OSPAR Guidelines on the granting of exemptions under the International Convention for the Control and Management of Ships' Ballast Water and Sediments, Regulation A-4, available at: https://helcom.fi/media/ documents/Joint-HELCOM_OSPAR-Guidelines.pdf (accessed 31 May 2020)

[4] Boudouresque CF., Verlaque M. (2005) Nature conservation, Marine Protected Areas, sustainable development and the flow of invasive species to the Mediterranean Sea, Scientific reports of the Port-Cros national park, France 21: 29-54.

[5] David M., Gollasch S., Leppakoski E. (2013) Risk assessment for exemptions from ballast water management - The Baltic Sea case study, Marine Pollution Bulletin 75 (2013) 205217. All rights reserved. http://dx.doi.org/10.1016/j. marpolbul.2013.07.031.

[6] David M., Gollasch S., Leppäkoski E., Hewitt C. (2015) Risk Assessment in Ballast Water Management, in David M, Gollasch S eds. Global Maritime Transport and Ballast Water Management. Springer, Netherland. pp. 133-169; DOI: 10.1007/978-94-017-9367-4_7.
[7] David M., Magaletti E., Kraus R., Marini M. (2019) Vulnerability to bioinvasions: Current status, risk assessment and management of ballast water through a regional approach The Adriatic Sea https://doi.org/10.1016/j.marpolbul. 2019.06.057.

[8] EU Biodiversity Strategy, (2011) available at http:// ec.europa.eu/environment/nature/info/pubs/docs/ brochures $/ 2020 \% 20$ Biod $\% 20$ brochure $\% 20$ final $\% 20$ lowres.pdf (accessed 31 May 2020)

[9] EU Marine Strategy Framework Directive, (2008, 2010, 2017) available at https://eur-lex.europa.eu/ (accessed 31 May 2020)

[10] Ferrario J., Caronni S., Occhipinti-Ambrogi A., Marchini A. (2017) Role of commercial harbours and recreational marinas in the spread of non-indigenous fouling species. Biofouling 33(8): 651-660. https://doi.org/10.1080/0892 7014.2017.1351958. Mar. Pollut. Bull. 55, 323-332. https:// doi.org/10.1016/j.marpolbul.2006.11.010.

[11] Gollasch S., David M. (2018) Ballast Water Management Convention Implementation Challenges, Ocean Yearbook 32, Boston.

[12] Gollasch S., David M., Broeg K., Heitmüller S., Karjalainen M., Lehtiniemi M., Normant-Saremba M., Ojaveer H., Olenin S., Ruiz M., Helavuori M., Sala-Pérez M., Strake S. (2020) Target species selection criteria for risk assessment based exemptions of ballast water management requirements, Ocean and Coastal Management 183 105021, available at https://doi.org/10.1016/j.ocecoaman.2019.105021.

[13] G7 (2017) International Convention for the Control and Management of Ships' Ballast Water and Sediments, Guidelines for Risk Assessment under Regulation A-4 of the BWM Convention G7, IMO, adopted on 7 July 2017, available at http://www.imo.org/en/KnowledgeCentre/ IndexofIMOResolutions/Marine-Environment-ProtectionC o m m it te e \% 28 M E P C 29 / D o c u m e n t s / MEPC.289\%2871\%29.pdf (accessed 31 May 2020)

[14] International Convention for the Control and Management of Ships' Ballast Water and Sediments, BWM Convention, (2004) available at: http://library.arcticportal.org/1913/1/ International $\% 20$ Convention $\% 20$ for $\% 20$ the $\% 20$ Control $\% 20$ and $\% 20 \mathrm{M}$ an a gem ent $\% 20$ of $\% 20$ Ships $\% 27 \% 20$ Ballast $\% 20$ Water $\% 20$ and $\% 20$ Sediments. pdf (accessed May 31, 2020)

[15] IMO, available at http://www.imo.org/ (accessed 31 May 2020)

[16] Katsanevakis S., Zenetos A., Belchior C., Cardoso AC. (2013) Invading European Seas: assessing pathways of introduction of marine aliens. Ocean Coastal Manage, 64-74. http://dx. doi.org/10.1016/j.ocecoaman.2013.02.024.

[17] Ministarstvo mora prometa i infrastructure (2012) Pravilnik o upravljanju i nadzoru balastnih voda (2012), Ministarstvo mora prometa i infrastrukture, NN 128/2012, available at: https://narodne-novine.nn.hr/clanci/sluzbeni/ 2012_11_128_2733.html (accessed May 31, 2020)

[18] Montenegro, Law on the prevention of pollution from ships, (2011), available at: http://extwprlegs1.fao.org/docs/pdf/ mne139383.pdf

[19] Ninčević Gladan Ž., Magaletti E., Scarpato A., Azzurro E., Bacci T., Berto D., Dulčić J., Gennaro P., Marusso V., Penna M., Rampazzo F., Sante Rende F., Romanelli G., Vidjak O., Trabucco B., Žuljević A. (2016) Final Report of Port Baseline Survey, BALMAS, IPA Adriatic Cross-border Cooperation Programme 2007 - 2013. 
[20] Ninčević Gladan, Ž., Vidjak O., Žuljević, A., Šolić, M., Cvitković, I., Matić Skoko S. (2016) Port Baseline Survey. (Final Report) BALMAS project. WP5. Activity 5.1, p. 31.

[21] Ojaveer, H., Galil, B.S., Campbell, M.L., Carlton, J.T., CanningClode, J., Cook, E.J., Davidson, A.D., Hewitt, C.L., Jelmert, A., Marchini, A., McKenzie, C.H., Minchin, D., OcchipintiAmbrogi, A., Olenin, S., Ruiz, G. (2015) Classification of nonindigenous species based on their impacts: considerations for application in marine management. PLoS Biol. 13 (4), e1002130. https://doi.org/10.1371/journal.pbio.1002130.

[22] Olenin S., Ojaveer H., Minchin D., Boelens R. (2015) Assessing exemptions under the ballast water management convention: preclude the Trojan horse, Marine Pollution Bulletin, DOI: https://doi.org/10.1016/j.marpolbul.2015. 12.043.

[23] Rak G. (2016) Legal and Policy Aspects Relevant for the Ships' Ballast Water Management in the Adriatic Sea Area. BALMAS Project Final Report, Rapporto ISPRA 250/2016, pp. 64.

[24] Rak G., Zec D., Markovčić Kostelac M., Joksimović D., Gollasche S., David M. (2018) The implementation of the ballast water management convention in the Adriatic Sea through States' cooperation: The contribution of environmental law and institutions; Marine Pollution Bulletin 147. DOI: 10.1016/j.marpolbul.2018.06.012.

[25] Stæhr, P.A., Jakobsen, H.H., Hansen, J.L.S., Andersen, P., StorrPaulsen, M., Christensen, J., Lundsteen, S., Göke, C., Carausu, M.C. (2016) Trends in Records and Contribution of Nonindigenous Species (NIS) to Biotic Communities in Danish Marine Waters. Scientific Report from the Danish
Centre for Environment and Energy (DCE) No. 179. Aarhus University, p. 44. http://dce2.au.dk/pub/SR179.pdf.

[26] Stuer-Lauridsen F., Drillet G., Thorbjørn Hansenc F., Saunders (2018) Same Risk Area: An area-based approach for the management of bio-invasion risks from ships' ballast water Marine Policy. Vol. 97, pp. 147-155, https://doi. org/10.1016/j.marpol.2018.05.009.

[27] Swedish Transport Agency (2018) Ballast Water Management Convention, available at https://www. transportstyrelsen.se/globalassets/global/sjofart/ dokument/miljoskydd/barlastvatten/information-onbwmc-exemptions.pdf (accessed 3 May 2020)

[28] Trindade de Castro M.C. (2012) Implementation of the Ballast Water Management Convention, 2004 - Background Information on the Subject and Enforcement Procedures, The United Nations-Nippon Foundation Fellowship Programme 2012 - 2013, New York, 2012. available at: https://www. un.org/Depts/los/nippon/unnff_programme_home/fellows_ pages/fellows_papers/castro_1213_brazil.pdf.

[29] Tsiamis, K., Zenetos, A., Deriu, I., Gervasini, E., \& Cardoso, A. C. (2018) The native distribution range of the European marine non-indigenous species. Aquatic Invasions, 13, 187198. https://doi.org/10.3391/ai.2018.13.2.01.

[30] Unknown, Institute for European Environmental Policy, available at: https://ieep.eu/work-areas/biodiversity/ invasive-alien-species.

[31] Wallentinus, I., Nyberg, C.D. (2007) Introduced marine organisms as habitat modifiers, Marine Pollution Bulletin Volume 55, Issues 7-9, 2007, pp. 323-332, available at https://doi.org/10.1016/j.marpolbul.2006.11.010. 